\title{
Differential actions of second messenger systems in the corpus luteum
}

\author{
M. C. Wiltbank, M. G. Diskin and G. D. Niswender \\ Animal Reproduction and Biotechnology Laboratory, Colorado State University, \\ Department of Physiology, Fort Collins, CO 80526, USA
}

Keywords; corpus luteum; sheep; protein kinase C; calcium; phosphoinositide turnover

\section{Background}

The corpus luteum develops from the follicular cells which remain following ovulation and secretes progesterone which is essential for normal pregnancy in domestic animals. In sheep, the corpus luteum must be present for at least 50 days if normal pregnancy is to be maintained (Casida \& Warwick, 1945). Progesterone is produced in the corpus luteum of domestic animals by two morphologically and functionally distinct steroidogenic cell types termed large and small luteal cells. In sheep, large cells average $29 \cdot 2 \mu \mathrm{m}$ in diameter (Rodgers et al., 1984) and can be morphologically distinguished by a spherical nucleus, stacks of rough endoplasmic reticulum, secretory granules and a highly involuted plasma membrane. Small cells average $15.8 \mu \mathrm{m}$ in diameter (Rodgers et al., 1984) and are distinguished by an irregularly shaped nucleus, large quantities of smooth endoplasmic reticulum, and numerous lipid droplets (for review see Niswender \& Nett, 1988).

After separation into relatively pure populations, biochemical differences have been clearly recognized between the two steroidogenic cell types (Ursely \& Leymarie, 1979; Koos \& Hansel, 1981; Fitz et al., 1982; Schwall et al., 1986). Purified preparations of small cells produce very little progesterone unless stimulated by luteinizing hormone $(\mathrm{LH})$ or other activators of the cyclic adenosine $3^{\prime}, 5^{\prime}$-monophosphate (cAMP)/protein kinase A second messenger pathway (Hoyer \& Niswender, 1985). In addition, LH may cause differentiation of small cells into large luteal cells (Donaldson \& Hansel, 1965; Farin et al., 1988) but it is not clear whether this action is mediated by the cAMP second messenger system. Large cells produce greater amounts of progesterone under basal conditions and treatment with LH or pharmacological activation of the cAMP second messenger pathway does not stimulate progesterone production (Hoyer \& Niswender, 1984, 1986; Harrison et al., 1987). Recently, it has become apparent that the phosphatidylinositide/free calcium/protein kinase $\mathrm{C}$ effector system is important in regulating luteal cell function. This review will focus on this intracellular regulatory system and its role in regulation of luteal cell function.

\section{Phosphatidylinositide metabolism}

By 1955 it had been shown that the turnover of certain membrane phospholipids, which were later identified as phosphatidic acid and phosphatidylinositol, was stimulated by acetylcholine (Hokin \& Hokin, 1955, 1958). This observation forms the basis of the subsequent discovery of the phosphoinositide second messenger system. Hormones or neurotransmitters which utilize this pathway appear to interact with a receptor which activates a specific signal-transducing $G$ protein (Gilman, 1987). The activated $G$ protein (probably the alpha subunit; Birnbaumer, 1987) then interacts with the membrane-bound phosphoinositide-specific phospholipase $\mathrm{C}$ enzyme (PLC). PLC cleaves phosphatidylinositol 4,5-bisphosphate (a minor phospholipid in cellular membranes) to yield 
inositol 1,4,5-trisphosphate $\left(\mathrm{IP}_{3}\right)$ and diacylglycerol. Both of these products are active second messengers with $\mathrm{IP}_{3}$ releasing calcium from calcium-sequestering compartments within the cell and diacylglycerol, along with free calcium, causing activation of protein kinase C (Berridge, 1987).

In the plasma membrane of ovine or bovine luteal cells phosphatidylinositol represents $4-6 \%$ of the total phospholipid (Zelinski et al., 1988; Allen et al., 1988). By labelling this phospholipid pool with ${ }^{32} \mathrm{P}$ or $\left[{ }^{3} \mathrm{H}\right]$ inositol the hormone-induced phosphoinositide turnover can be quantified (Lapetina \& Siess, 1987; Huckle \& Conn, 1987). Using this methodology, prostaglandin (PG) F-2a. increases phosphoinositide breakdown in ovarian cells from the rat (Leung, 1985; Leung et al., 1986), cow (Davis et al., 1987b, 1988, 1989), pig (Veldhuis, 1987), and sheep (Jacobs et al., 1987). Most investigators have also reported an increase in phosphoinositide turnover following treatment of luteal cells with human chorionic gonadotrophin (hCG) or LH (Davis et al., 1986, 1987b; Allen et al., 1988), although others reported no effect of LH administration on phosphoinositide turnover (Leung, 1985; Jacobs et al., 1987). It seems confusing that the phosphoinositide second messenger pathway could be activated by both a luteotrophic hormone (LH) and a luteolytic hormone (PGF-2 $\alpha$ ), since these hormones have opposite effects. Possible explanations include: (1) different cell types show different responses to phosphoinositide turnover; (2) hormones cause multiple effects on the same cell through different second messenger pathways; or (3) there is a functionally significant difference in the magnitude of the LH and PGF-2 $\alpha$ effect on phosphoinositide turnover (Leung \& Wang, 1989).

\section{Protein kinase C}

Protein kinase $\mathrm{C}$ is an essential component in the intracellular action of a number of hormones and neurotransmitters (Nishizuka, 1986). Under physiological conditions the activity of protein kinase $\mathrm{C}$ is dependent upon membrane phospholipids and is regulated by concentrations of free calcium and diacylglycerol (Rando, 1988). Pharmacologically, protein kinase C can be activated by tumour-promoting phorbol esters such as phorbol 12-myristate 13-acetate (PMA). Physiological or pharmacological activation of protein kinase $C$ causes the enzyme to bind to the phospholipids in cellular membranes, and this response has been utilized to evaluate the state of activation for protein kinase C (Thomas et al., 1987).

Protein kinase $\mathrm{C}$ activity has been detected in luteal cells from cattle, sheep and pigs (Davis \& Clark, 1983; Noland \& Dimino, 1986; Wheeler \& Veldhuis, 1987; Hoyer \& Kong, 1989; Wiltbank et al., 1989b). Protein kinase C activity has been reported to be $2 \cdot 7$-fold greater in pig corpora lutea than in medium-sized follicles (Noland \& Dimino, 1986), whereas protein kinase A activity was greater in follicles than in corpora lutea (Dimino et al., 1981). Three chromatographically distinct forms of protein kinase $\mathrm{C}$ have been detected in the cytosol from pig luteal cells (Wheeler \& Veldhuis, 1989) and these different forms of protein kinase $\mathrm{C}$ may have distinct actions (Kosaka et al., 1988). We have found that total protein kinase $C$ activity was much greater (per mg protein) in large than in small ovine luteal cells under control conditions (Fig. 1). As noted for protein kinase C in other tissues, phosphatidylserine, diacylglycerol and calcium were required for maximal activation. In addition, treatment with PMA caused translocation of protein kinase $C$ from a cytosolic location to the membrane-attached configuration (Wiltbank et al., 1989b). Hoyer \& Kong (1989) reported that the preferred endogenous substrate for phosphorylation by protein kinase $\mathrm{A}$ in small cells and by protein kinase $\mathrm{C}$ in large cells is a protein of $M_{\mathrm{r}}=37000$. The identity of this protein and its role in the actions of protein kinases $\mathrm{A}$ and $\mathrm{C}$ have not been elucidated. Perhaps part of the differentiation of large luteal cells, from either follicular cells or small luteal cells, involves transformation from a cell primarily regulated by the protein kinase A pathway to one regulated by the protein kinase $\mathrm{C}$ effector system.

Paradoxical results have been reported from studies in which cultured luteal cells were treated with phorbol esters to activate protein kinase C. In some studies there appeared to be a slight 


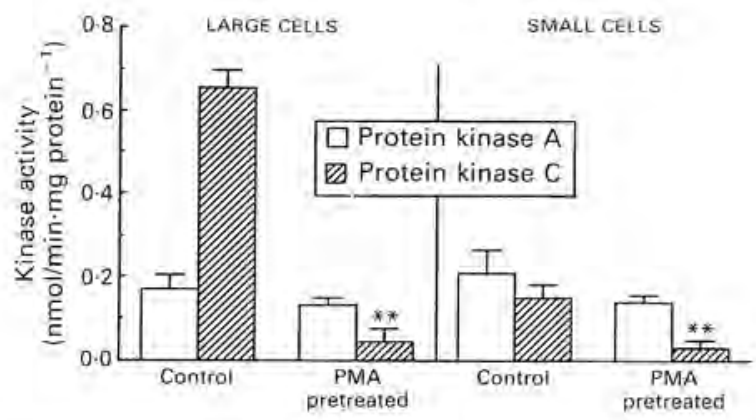

Fig, 1. Effect of $18 \mathrm{~h}$ pretreatment with $1 \mu \mathrm{M}$-phorbol 12-myristate 13-acetate (PMA) or ethanol vehicle (Control) on total protein kinase $\mathrm{C}$ or cyclic adenosine $3^{r}, 5^{\prime}$-monophosphate-dependent protein kinase ( protein kinase A) activity in large or small luteal cells. Values are mean \pm s.e.m. for 4 experiments. ${ }^{* *} P<0 \cdot 05$. Activity measurements were performed as previously described. (From Wiltbank et al., 1989b.)

stimulation of progesterone secretion from small bovine luteal cells in response to phorbol esters (Brunswig et al., 1986; Alila et al., 1988). However, PMA treatment inhibited progesterone secretion from small bovine luteal cells which were maximally stimulated with LH (Benhaim et al., 1987). In non-stimulated small ovine luteal cells we found no effect of PMA (at any dose from $0 \cdot 1$ to 1000-nM) on progesterone production. However, activation of protein kinase $\mathrm{C}$ with PMA was inhibitory to progesterone production by small cells stimulated with $\mathrm{LH}$, forskolin or dibutyryl cAMP (Fig. 2). This suggests that the inhibitory action of protein kinase $C$ on the small ovine luteal cell occurs, at least in part, after LH binding and cAMP production. Interestingly, metabolism of 25-hydroxycholesterol (an estimate of cholesterol side-chain cleavage enzyme activity; Toaff et al., 1982) was not inhibited by PMA, suggesting that protein kinase $\mathrm{C}$ acts before the cholesterol side-chain cleavage enzyme (Fig. 2).

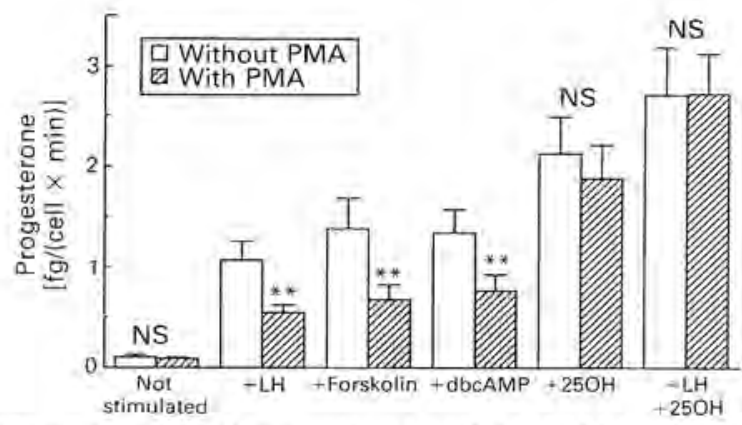

Fig. 2. Effect of 200 nM-phorbol 12-myristate 13-acetate (PMA) on progesterone production by non-stimulated small ovine luteal cells or by small cells treated with $100 \mathrm{ng} \mathrm{LH} / \mathrm{ml}(\mathrm{LH})$, $50 \mu \mathrm{M}$-forskolin, $10 \mathrm{mM}$-dibutyryl cyclic adenosine 3',5'-monophosphate (dbcAMP), or $20 \mu \mathrm{g}$ 25 -hydroxycholesterol $/ \mathrm{ml}(25 \mathrm{OH})$ during a 2 -h incubation. These doses were found to be maximally stimulatory in preliminary experiments. ${ }^{* *} P<0.001$; NS $=$ not significant. Values are mean \pm s.e. for 5 experiments, each done in triplicate cell culture wells. (From Wiltbank et al.; $1989 \mathrm{~b}$.

In ovine large luteal cells PMA was a potent inhibitor of progesterone secretion during incubation times that did not cause depletion of intracellular protein kinase $\mathrm{C}$ concentrations (Wiltbank et al., 1989b). Other investigators have also reported that PMA inhibits progesterone production by mixed or large ovine luteal cells (Conley \& Ford, 1989; Hoyer \& Marion, 1989). In contrast, activation of protein kinase $\mathrm{C}$ was reported to have no effect on progesterone production 
by bovine large luteal cells (Alila et al., 1988). This could be due to a species difference between the luteal cells of sheep and cattle. We recently investigated the action of PMA on bovine large luteal cells and found a small but significant inhibitory effect of PMA on basal progesterone production by non-stimulated large luteal cells. However, in large luteal cells in which progesterone secretion had been stimulated by high-density lipoprotein there was a profound inhibition of progesterone secretion by PMA and PGF-2 $\alpha$ (Fig. 3). These results suggest that either protein kinase $\mathrm{C}$ is inhibitory to lipoprotein utilization by bovine large luteal cells or that the inhibitory effects of protein kinase $\mathrm{C}$ cannot be detected in large luteal cells which are producing low quantities of progesterone. In either case, since lipoproteins are continuously available to luteal cells under physiological conditions, it appears that protein kinase $\mathrm{C}$ is an important pathway for inhibiting progesterone production by large ovine and bovine luteal cells. Other actions of protein kinase C within luteal cells include stimulation of PGF-2 $\alpha$ synthesis (Veldhuis \& Demers, 1987) and relaxin release (Taylor \& Clark, 1988),

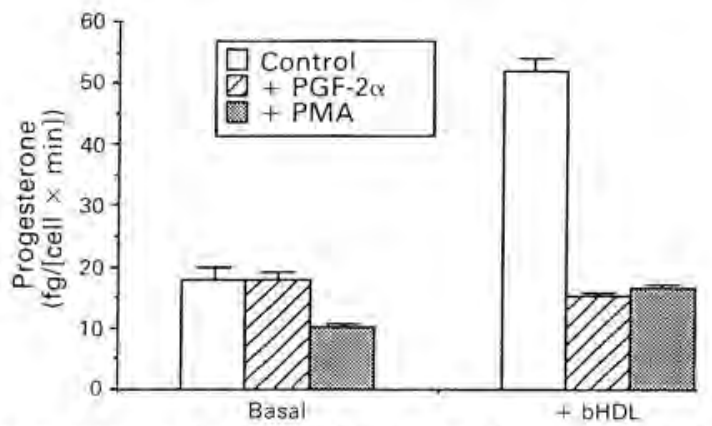

Fig. 3. Efrect of 100 nm-prostaglandin F-2 $\alpha$ (PGF-2 $\alpha$ ) or 10 nM-phorbol 12-myristate 13-acetate (PMA) on progesterone secretion (during 2-h incubation) by large bovine luteal cells (15000 large cells $/ \mathrm{ml}$ ) in the presence or absence of bovine high density lipoprotein cholesterol (bHDL) at $100 \mu \mathrm{g} / \mathrm{ml}$. Values are mean \pm s.d. for triplicate wells from one representative experiment; another experiment yielded similar results.

To understand the physiological relevance of this intracellular effector system it is important to consider the question of which hormones, if any, activate the protein kinase $\mathrm{C}$ pathway in luteal cells. Measurement of hormonally induced phosphoinositide breakdown gives suggestive evidence for activation of protein kinase $\mathrm{C}$, but is not a direct measure of such activation. The best method for measuring protein kinase $\mathrm{C}$ activation at the present time is evaluation of relative cytosolic versus membrane-bound levels of protein kinase $\mathrm{C}$ after specific hormonal treatments (Thomas et al., 1987; Witters \& Blackshear, 1987). We have utilized this methodology to evaluate activation of protein kinase $\mathrm{C}$ in large and small luteal cells after a 15-min treatment with PMA (positive control), LH or PGF- $2 \alpha$. As expected, PMA activates protein kinase $C$ both in large and small luteal cells. Treatment with $\mathrm{LH}$ did not activate protein kinase $\mathrm{C}$ in either luteal cell type, whereas treatment with PGF- $2 \alpha$ caused membrane association of protein kinase $\mathrm{C}$ in large but not small luteal cells (Fig. 4).

The data presented above are consistent with PGF- $2 \alpha$ acting through the protein kinase C effector pathway. More direct evidence for this hypothesis could be obtained by blocking the protein kinase $C$ pathway and then evaluating whether the effects of PGF- $2 \alpha$ were inhibited. There were two difficulties in doing this experiment. The first difficulty was to find a specific inhibitor of protein kinase C. Sphingosine, which reportedly displaces diacylglycerol or PMA from the protein kinase C-phospholipid complex (Jaken \& Leach, 1988), caused death of luteal cells (unpublished observations; Hoyer \& Marion, 1989). Two other inhibitors of protein kinase C (staurosporine and $\mathrm{H}-7$ [1-\{5-isoquinolinylsulphonyl $\}-2$-methylpiperazine $]$ ) act at the ATP binding site to block phosphorylation (Nakadate et al., 1988) and our experience indicates that these inhibitors block 


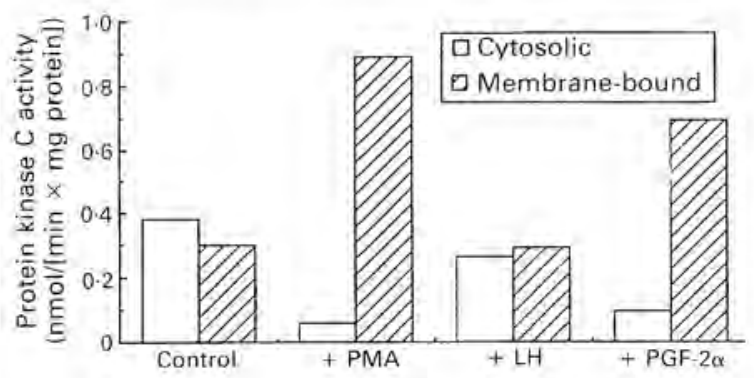

Fig. 4. Quantities of protein kinase C activity in the cytosolic and membrane-bound fractions of large luteal cells after 15 -min treatment with vehicle (control), $1 \mu \mathrm{M}$-phorbol 12-myristate 13 acetate (PMA), $100 \mathrm{ng} \mathrm{LH} / \mathrm{ml}(\mathrm{LH})$ or $1 \mu \mathrm{M}$-prostaglandin F-2 $\alpha\left(\mathrm{PGF}_{2 \alpha}\right)$. These data represent the mean from one representative experiment. Another experiment yielded similar results.

both protein kinase $\mathrm{A}$ as well as protein kinase $\mathrm{C}$ activity (unpublished observations). Other protein kinase $\mathrm{C}$ inhibitors are also non-specific since they inhibit a wide variety of calciumdependent enzymes (Rando, 1988). Another approach used successfully with a number of cell types is to 'down regulate' protein kinase $\mathrm{C}$ activity by treatment with high concentrations of phorbol ester (Witters \& Blackshear, 1987). Treatment of large or small luteal cells for $18 \mathrm{~h}$ with $1 \mu \mathrm{M}$-PMA decreased protein kinase $\mathrm{C}$ activity to levels that were not significantly different from zero while protein kinase A concentrations (Fig. 1), non-specific kinase activity and cell viability were not significantly altered (Wiltbank et al., 1989b). These protein kinase C-deficient luteal cells showed no response to acute treatment with PMA. Therefore, these protein kinase C-deficient luteal cells appeared to offer a good model for evaluating whether protein kinase $\mathrm{C}$ was part of the mechanism of action for specific hormones.

A second difficulty which we encountered was in obtaining a consistent effect of PGF- $2 \alpha$ in cultured luteal cells. Various researchers have reported stimulatory (Speroff \& Ramwell, 1970), inhibitory (Fitz et al., 1984) or no (Litch \& Condon, 1988) effects of PGF-2 $\alpha$ on progesterone secretion by cultured luteal cells. There are probably at least two reasons for these contrasting results. First, purified cell types are generally not used and the sensitivity of the assay system is decreased if the primary action of PGF-2 $\alpha$ is on one specific cell type. Second, luteal cells in culture are deficient in cholesterol substrate and therefore produce progesterone at such low levels it is difficult to detect an inhibition of progesterone production (Pate \& Nephew, 1988; Grummer \& Carroll, 1988). We attempted to overcome these problems by utilizing purified large and small luteal cells which were incubated in the presence of maximally stimulatory doses of high-density lipoprotein (to provide cholesterol substrate). In this system PGF-2a (doses of $30-30000 \mathrm{nM}$; in the presence or absence of $\mathrm{LH}$ ) caused a consistent inhibition of progesterone production by large but not small luteal cells (Wiltbank et al., 1990a). Large luteal cells that were made protein kinase C-deficient were no longer inhibited by PGF-2 $\alpha$ (Fig. 5). This did not seem to be the result of a decreased sensitivity to PGF-2 $\alpha$, since protein kinase $\mathrm{C}$-deficient luteal cells were not inhibited by doses of PGF-2 $\alpha$ which were 300 times the dose which maximally inhibited progesterone production by normal large luteal cells (Wiltbank et al, 1990a). These results are consistent with PGF-2 $\alpha$ acting on the large luteal cell through the protein kinase $\mathrm{C}$ second messenger pathway.

However, not all the actions of PGF- $2 \alpha$ could be explained by activation of the protein kinase C pathway since PGF- $2 \alpha$ continued to cause cell damage and eventual cell death in normal or protein kinase C-deficient large luteal cells (unpublished observations). In addition, treatment with PMA did not cause luteal cell death (Wiltbank et al., 1989b; Hoyer \& Marion, 1989). Therefore, although the acute inhibition of steroidogenesis caused by PGF- $2 \alpha$ could be attributable to activation of the protein kinase $\mathrm{C}$ pathway, it does not appear that the cytotoxic effects of PGF- $2 \alpha$ are mediated through protein kinase $\mathrm{C}$. 


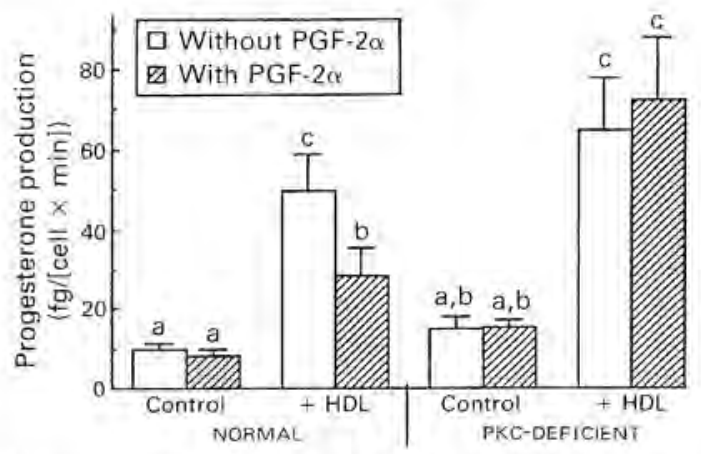

Fig. 5. Effect of $1 \mu \mathrm{M}$-prostaglandin $\mathrm{F}-2 \alpha\left(\mathrm{PGF}_{2 u}\right)$ on high density lipoprotein-stimulated (HDL; $200 \mu \mathrm{g}$ cholesterol $/ \mathrm{ml}$ ) production of progesterone by normal or protein kinase $\mathrm{C}$ deficient (PKC-deficient) large ovine luteal cells. Values are mean \pm s.e.m.; $n=6$ replicates each run in triplicate. Values with different letters are significantly different, $P<0.01$. (From Wiltbank et al., 1990a.)

\section{Free intracellular calcium concentrations}

For many years it has been known that free intracellular calcium concentrations are elevated in nerves and muscles in response to action potentials. In cells which do not generate action potentials, recent evidence also indicates that changes in free intracellular calcium concentration are an important aspect of hormonal regulation (see reviews by Carafoli, 1987; Gallacher, 1988). Calcium release from intracellular stores is thought to be caused by $\mathrm{IP}_{3}$ binding to a specific receptor on the endoplasmic reticulum or calciosome and this binding causing opening of a specific calcium channel (Exton, 1988), In addition, inositol polyphosphates, including $\mathrm{IP}_{3}$ or inositol 1,3,4,5tetrakisphosphate, may open calcium channels on the plasma membrane causing an influx of calcium from the extracellular fluid (Kuno \& Gardner, 1987; Gallacher, 1988). Other mechanisms for calcium influx in the absence of action potentials have also been postulated (Gallacher, 1988).

It has been speculated for many years that calcium influx is associated with secretion of progesterone by luteal cells (Higuchi et al., 1976). Luteolytic hormones may also act by increasing free intracellular calcium concentrations since pharmacological manipulation of intracellular calcium concentrations cause effects which are similar to the effects of PGF-2 $\alpha$ (Behrman et al., 1986; Baum \& Rosberg, 1987). Investigators using calcium-sensitive fluorescent dyes have shown that PGF-2 $\alpha$ causes an increase in free intracellular calcium concentrations (Davis et al, 1987b; Leung et al., 1989; Alila et al., 1989). LH and hCG have also been shown to increase free intracellular calcium concentrations in bovine luteal cells (Davis et al., 1986, 1987a; Alila et al., 1989). Again the question arises as to how the same second messenger system could mediate the action of hormones which have opposite effects on secretion of progesterone.

We have recently evaluated the hormonal regulation of free intracellular calcium concentrations in ovine small and large luteal cells (Wiltbank et al., 1989a) using a dual-wavelength calcium-sensitive dye, fura-2 (Grynkiewicz et al., 1985). Fura-2 fluorescence was evaluated with a computer-enhanced microscopic imaging system (Connor, 1986; Cohan et al., 1987; Mattson et al., 1988) which allowed monitoring of the calcium concentrations in individual luteal cells in response to specific treatments. As a positive control, cells were treated with $1 \mu \mathrm{M}-\mathrm{A} 23187$ (calcium ionophore) which caused a dramatic increase in free intracellular calcium concentrations in large and small luteal cells (Fig. 6). In small luteal cells, free calcium concentrations increased very rapidly but returned to control levels by 2 min after A23187 treatment, while calcium concentrations in adjacent large cells had not returned to baseline by 20 min after treatment. Since small and large cells were adjacent in this experiment and therefore exposed to similar concentrations of 
A23187 it seems likely that calcium extrusion mechanisms are more effective in the small than in the large luteal cells. Treatment with $1 \mu \mathrm{M}-\mathrm{A} 23187$ causes cell death in large but not small luteal cells (Hoyer \& Marion, 1989). Therefore, it seems likely that sustained elevations in free intracellular calcium concentrations are cytotoxic in large luteal cells.

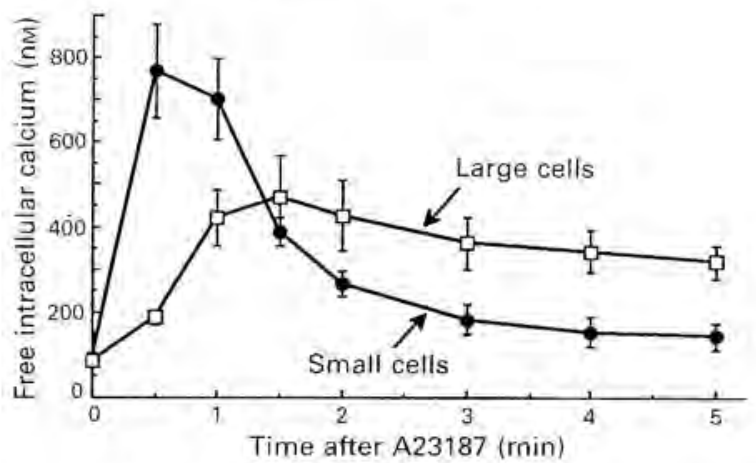

Fig. 6. Effect of $1 \mu \mathrm{M}-\mathrm{A} 23187$ on free intracellular calcium concentration within small and large luteal cells (mean \pm s.e.). For large cells $(n=6)$, free intracellular calcium concentration is greater $(P<0.05)$ than at Time 0 for all time points except $30 \mathrm{sec}$ after A23187. For small cells $(n=5)$, free intracellular calcium concentration is greater $(P<0.05)$ than at Time 0 at 30,60, and $90 \mathrm{sec}$, but is not different at 2,3,4 or $5 \mathrm{~min}$ after A23187. Treatment with DMSO (vehicle) caused no significant change in free intracellular calcium concentrations in either cell type. (From Wiltbank et al., 1989a.)

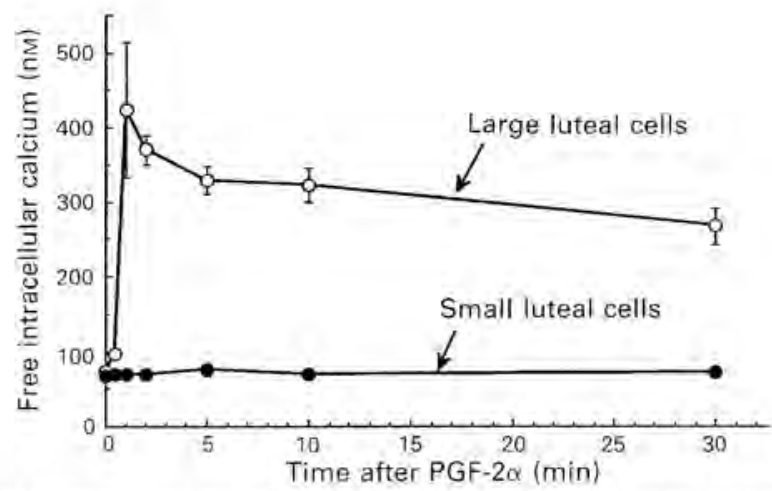

Fig. 7. Effect of $1 \mu \mathrm{M}$-prostaglandin F-2 $\alpha$ on free intracellular calcium concentrations in small and large luteal cells. Calcium concentrations were measured by computer imaging of fura2 fluorescence. Data are from 4 replicates of this experiment with 5-8 large cells and 2-4 small cells evaluated per replicate. Values are mean \pm s.e. (if s.e. larger than symbol). (From Wiltbank et al., 1989a.)

Treatment with PGF-2 $\alpha$ caused dramatic increases in free intracellular concentrations of calcium within large but not small luteal cells (Fig. 7). This measurement system allowed visualization of the 5-20-fold increases in free calcium concentrations within large cells while the levels in adjacent small luteal cells were not changed (Wiltbank et al., 1989a). This is further evidence that large and small ovine luteal cells have clear functional differences, with PGF- $2 \alpha$ responsiveness being localized to large luteal cells which have the high affinity PGF-2 $\alpha$ receptors (Fitz et al., 1982; Balapure et al., 1989). Treatment with a high dose of PGF- $2 \alpha(1 \mu \mathrm{M})$ caused an increase in concentrations of free calcium within all large luteal cells (Wiltbank et al., 1989a). Lower doses of PGF-2 $\alpha$ 
increased free calcium in only a portion of the large luteal cells within 10 min suggesting that large luteal cells differ in their responsiveness to this hormone. After treatment with PGF- $2 \alpha$, the free calcium concentration in large luteal cells remained elevated for at least $30 \mathrm{~min}$ (Fig. 7). It appeared that most of this increase in free intracellular calcium concentration was due to influx from extracellular sources. We conclude that PGF- $2 \alpha$ causes a sustained elevation in free calcium concentration specifically in the large luteal cell. It seems likely that this sustained elevation in free calcium is cytotoxic to large luteal cells as it is to other cell types (Choi, 1985; Mayer \& Westbrook, 1987; Mattson et al., 1988). In these experiments we could find no evidence for an LH-induced increase in concentrations of free intracellular calcium within either large or small luteal cells (Wiltbank et al., 1989a).

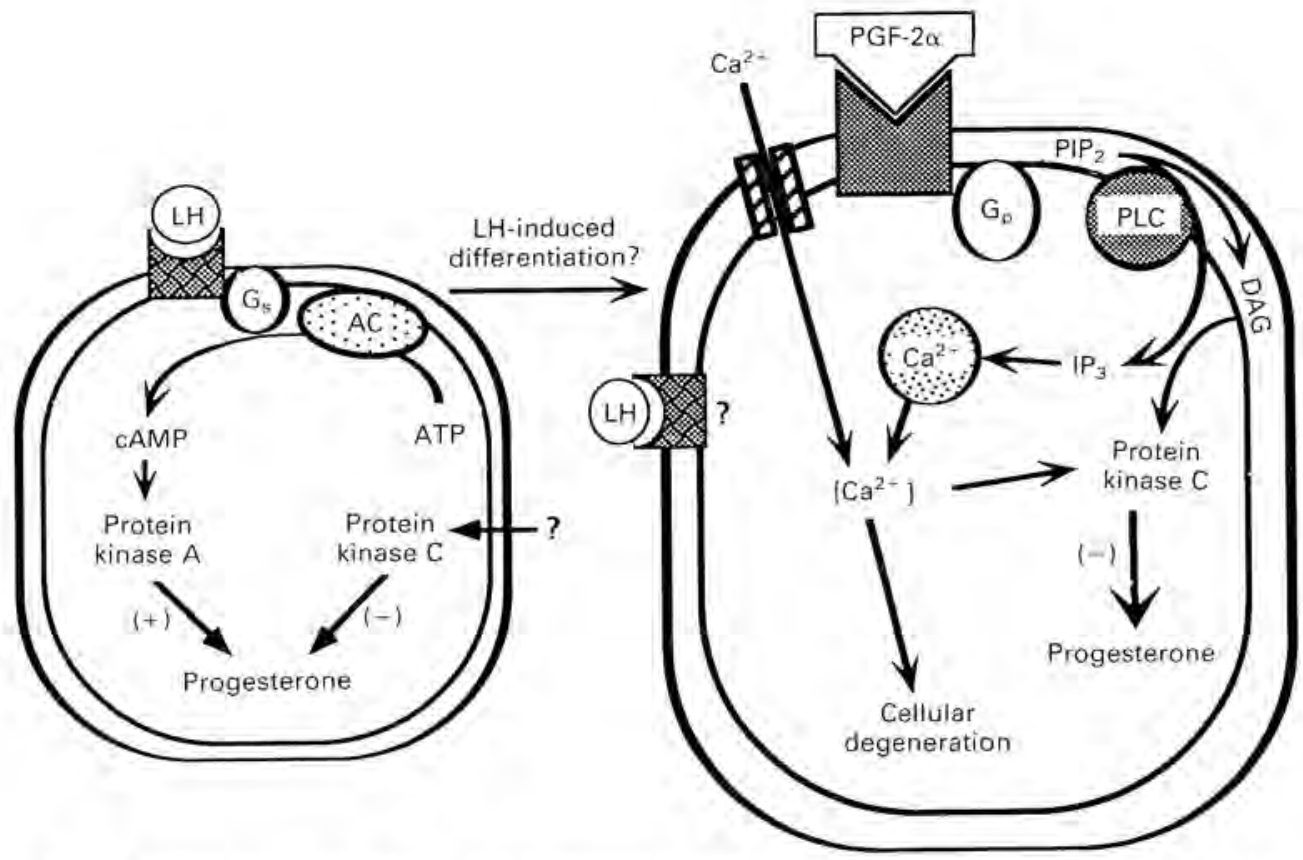

Fig. 8. Current working model for the second messenger pathways involved in regulating the small (left side) and large (right) luteal cells. See summary in text for details. Abbreviations are: luteinizing hormone (LH), G-protein causing stimulation of adenylate cyclase (Gs), adenylate cyclase (AC), adenosine triphosphate (ATP), cyclic adenosine monophosphate (cAMP), prostaglandin F-2 $\alpha$ (PGF-2 $\alpha$ ), free calcium concentration ( $\left[\mathrm{Ca}^{2+}\right]$ ), phosphatidylinositol 4,5bisphosphate $\left(\mathrm{PIP}_{2}\right)$, inositol 1,4,5-trisphosphate $\left(\mathrm{IP}_{3}\right)$, diacylglycerol (DAG).

\section{Summary}

Our current working hypothesis for the intracellular mechanism of action for LH and PGF-2 $\alpha$ is shown in Fig. 8. Luteinizing hormone appears to act primarily on the small luteal cell through the $\mathrm{cAMP} /$ protein kinase A effector system and thereby stimulates secretion of progesterone. Activation of the protein kinase $\mathrm{C}$ effector pathway is inhibitory to progesterone secretion from stimulated small luteal cells but it is not clear which hormones, if any, activate this effector system. Results from studies in whole animals suggest that LH may also stimulate differentiation of small luteal cells into large luteal cells (Donaldson \& Hansel, 1965; Farin et al., 1988). Although there are $\mathrm{LH}$ receptors on large luteal cells, $\mathrm{LH}$ treatment does not stimulate progesterone secretion and does 
not appear to activate any of the second messenger pathways which we have examined. Prostaglandin F-2 $\alpha$ appears to act on the large luteal cell through free intracellular calcium and protein kinase $\mathrm{C}$ effector systems. Apparently, PGF-2 $\alpha$-induced activation of protein kinase $\mathrm{C}$ results in the acute inibition of progesterone production seen in the first $8 \mathrm{~h}$ after PGF- $2 \alpha$ treatment. The cytotoxic effects of PGF-2 $\alpha$ on the large luteal cell (Fitz et al., 1984; Braden et al., 1988) may be caused by a sustained elevation in free intracellular calcium concentrations. No direct effects of PGF-2a on small luteal cells have been detected (no inhibition of progesterone production, no activation of protein kinase $\mathrm{C}$, no increase in free intracellular calcium), which is consistent with an absence of high affinity PGF-2 $\alpha$ receptors on this cell type. The cytotoxic effects of PGF- $2 \alpha$ on small luteal cells and endothelial cells (Braden et al., 1988) may be caused by decreases in luteal blood flow (Niswender et al., 1975; Wiltbank et al., 1990b), actions of cytotoxic agents released by large luteal cells, or increases in cytotoxic white blood cells (Murdoch, 1987; Bagavandoss et al., 1988).

We thank G. J. Wiepz for graphical assistance with the colour model; Dr M. H. Mayan and K. L. Sutherland for technical assistance; K. A. Miller for secretarial assistance; Dr S. B, Kater, Dr P. B. Guthrie and Dr M. P. Mattson for collaboration with calcium measurements; J. A. Flores for collaboration with lipoprotein stimulation; and Dr H. R. Sawyer and C. L. Moeller for computer support.

\section{References}

Alila, H.W., Corradino, R.A. \& Hansel, W. (1989) Differential effects of luteinizing hormone on intracellular free $\mathrm{Ca}^{2+}$ in small and large bovine luteal cells. Endocrinology 124, 2314-2320.

Alila, H.W., Dowd, J.P., Corradino, R.A., Harris, W.V. \& Hansel, W. (1988) Control of progesterone production in small and large bovine luteal cells separated by flow cytometry. J. Reprod. Fert. 82, 645-655.

Allen, R.B., Su, H.C., Snitzer, J. \& Dimino, M.J. (1988) Rapid decreases in phosphatidy!-inositol in isolated luteal plasma membranes after stimulation by luteinizing hormone. Biol. Reprod. 38, 79-83.

Bagavandoss, P., Kunkel, S.L., Wiggins, R.C. \& Keyes, P.L. (1988) Tumor necrosis factor-a (TNA-a) production and localization of macrophages and T lymphocytes in the rabbit corpus luteum. Endocrinology 122, $1185-1187$.

Balapure, A.K., Caicedo, I.C., Kawada, K., Watt, D.S., Rexroad, C.E., Jr \& Fitz, T.A. (1989) Multiple classes of prostaglandin $\mathrm{F}_{20}$ binding sites in subpopulations of ovine luteal cells. Biol. Reprod. 41, 385-392.

Baum, M.S. \& Rosberg, S. (1987) A phorbol ester, phorbol 12-myristate 13-acetate, and a calcium ionophore, A23187, can mimic the luteolytic effect of prostaglan$\operatorname{din} \mathrm{F}_{2 a}$ in isolated rat luteal cells. Endocrinology 120, $1019-1026$.

Behrman, H.R., Aten, R.F., Luborsky, J.L., Polan, M.L., Miller, J.G.O. \& Soodak, L.K. (1986) Purines, prostaglandins and peptides-Nature and cellular mechanisms of action of local assist and assassin agents in the ovary. J. Anim. Sci. 62 (Suppl. 2), 14-24.

Benhaim, A., Herrou, M., Mittre, H. \& Leymarie, P. (1987) Effects of phorbol esters on steroidogenesis in small bovine luteal cells. FEBS Lett. 223, 321-326.

Berridge, M.J. (1987) Inositol trisphosphate and diacy]glycerol: Two interacting second messengers. Ann. Rev. Biochem. 56, 159-193.

Birnbaumer, L. (1987) Which G protein subunits are the active mediators in signal transduction? Trends in Pharm. Sci. 8, 209-211.

Braden, T.D., Gamboni, F. \& Niswender, G.D. (1988) Effects of prostaglandin $\mathrm{F}_{20}$-induced luteolysis on the populations of cells in the ovine corpus luteum. Biol. Reprod. 39, 245-253.

Brunswig, B., Mukhopadhyay, A.K., Budnik, L.T, Bohnet, H.G. \& Leidenberger, F.A. (1986) Phorbol ester stimulates progesterone production by isolated bovine luteal cells. Endocrinology 118, 743-749.

Carafoli, E. (1987) Intracellular calcium homeostasis. Ann. Rev. Biochem. 56, 395-433.

Casida, L.E. \& Warwick, E.J. (1945) The necessity of the corpus luteum for maintenance of pregnancy in the ewe. J. Anim. Sci. 4, $34-36$.

Choi, D.W. (1985) Glutamate neurotoxicity in cortical cell culture is calcium dependent. Neurosci. Lett. $\mathbf{5 8}$, 293-297.

Cohan, C.S., Connor, J.A. \& Kater, S.B. (1987) Electrically and chemically mediated increases in intracellular calcium in neuronal growth cones. $J$. Neurosci. 7, 3588-3600.

Conley, A.J. \& Ford, S.P. (1989) Effects of TPA, A23187, and prostaglandin $\mathrm{F}_{2 a}$ on progesterone synthesis by dispersed ovine luteal cells. Biol. Reprod. 40, 1224 1230.

Connor, J.A. (1986) Digital imaging of free calcium changes and of spatial gradients in growing processes in single, mammalian central nervous system cells. Proc. natn. Acad. Sci. USA 83, 6179-6183.

Davis, J.S. \& Clark, M.R. (1983) Activation of protein kinase in the bovine corpus luteum by phospholipid and $\mathrm{Ca}^{2+}$. Biochem. J.214, 569-574.

Davis, J.S., West, L.A., Weakland, L.L. \& Farese, R.V. (1986) Human chorionic gonadotropin activates the inositol, 1,4.5-trisphosphate- $\mathrm{Ca}^{2+}$ intracellular signalling system in bovine luteal cells. FEBS Lett. 2208, 287-291, 
Davis, J.S., Weakland, L.L., Farese, R.V. \& West, L.A. (1987a) Luteinizing hormone increases inositol triphosphate and cytosolic free $\mathrm{Ca}^{2+}$ in isolated bovine luteal cells, $J$, biol. Chem. 262, 8515-8521.

Davis, J.S., Weakland, L.L., Weiland, D.A., Farese, R.V. \& West, L.A. (1987b) Prostaglandin $\mathrm{F}_{2 \mathrm{a}}$ stimulates phosphatidylinositol 4,5-bisphosphate hydrolysis and mobilizes intracellular $\mathrm{Ca}^{2+}$ in bovine luteal cells. Proc. natn. Acad. Sci. USA 84, 3728-3732.

Davis, J.S., Alila, H.W., West, L.A., Corradino, R.A. \& Hansel, W. (1988) Acute effects of prostaglandin $F_{20}$ on inositol phospholipid hydrolysis in the large and small cells of the bovine corpus luteum. Molec. cell. Endoerinol. 58, 43-50.

Davis, J.S., Alila, H.W., West, L.A., Corradino, R.A., Weakland, L.L. \& Hansel, W. (1989) Second messenger systems and progesterone secretion in the small cells of the bovine corpus luteum: effects of gonadotropins and prostaglandin $\mathrm{F}_{2 a^{*}} . J$. Steroid Biochem. 32, 643-649.

Dimino, M.J., Bieszczad, R.R. \& Rowe, M.J. (1981) Cyclic AMP-dependent protein kinase in mitochondria and cytosol from different-sized follicles and corpora lutea of porcine ovaries. J. biol. Chem. 256, 10876 10882.

Donaldson, L. \& Hansel, W. (1965) Histological study of bovine corpora lutea. J. Dairy Sci. 48, 905-909.

Exton, J.H. (1988) Mechanisms of action of calciummobilizing agonists: some variation on a young theme. FASEB J, 2, 2670-2676.

Farin, C.E., Moeller, C.L., Mayan, H., Gamboni, F., Sawyer, H.R. \& Niswender, G.D. (1988) Effect of luteinizing hormone and human chorionic gonadotropin on cell populations in the ovine corpus luteum. Biol. Reprod 38, 413-421.

Fitz, T.A., Mayan, M.H., Sawyer, H.R. \& Niswender, G.D. (1982) Characterization of two steroidogenic cell types in the ovine corpus luteum. Biol. Reprod. 27, 703-711.

Fitz, T.A., Mock, E.J., Mayan, M.H. \& Niswender, G.D. (1984) Interactions of prostaglandins with subpopulations of ovine luteal cells. II. Inhibitory effects of $\mathrm{PGF}_{2 \mathrm{a}}$ and protection by $\mathrm{PGE}_{2}$. Prostaglandins 28, 127-138.

Gallacher, D.V. (1988) Control of calcium influx in celis without action potentials. News in Physiol. Sci. 3, $244-249$.

Gilman, A.G. (1987) G proteins: transducers of receptor-generated signals. Ann. Rev. Biochem. 56, 615-649.

Grummer, R.R. \& Carroll, D.J. (1988) A review of lipoprotein cholesterol metabolism: importance to ovarian function. J. Anim. Sci, 66, 3160-3173,

Grynkiewicz, G., Poenie, M. \& Tsien, R.Y. (1985) A new generation of $\mathrm{Ca}^{2+}$ indicators with greatly improved fluorescence properties, J. biol. Chem. 260, 3440-3450.

Harrison, L.M., Kenny, N. \& Niswender, G.D. (1987) Progesterone production, $\mathrm{LH}$ receptors, and oxytocin secretion by ovine luteal cell types on Days 6,10 and 15 of the oestrous cycle and Day 25 of pregnancy. $J$. Reprod. Fert. 79, 539-548.

Higuchi, T., Kaneko, A., Abel, J.H., Jr \& Niswender G.D. (1976) Relationship between membrane potential and progesterone release in ovine corpora lutea. Endocrinology 99, 1023-1032.
Hokin, L.E. \& Hokin, M.R. (1955) Effects of acetylcholine on the turnover of phosphoryl units in individual phospholipids of pancreas slices and brain cortex slices. Biochim. Biophys. Acta 18, 102-110.

Hokin, L.E. \& Hokin, M.R. (1958) The presence of phosphátidic acid in animal tissues. $J$, biol. Chem 233, 800-804.

Hoyer, P. \& Niswender, G.D. (1985) The regulation of steroidogenesis is different in the two types of ovine luteal cells. Can. J. Physiol. Pharmacol. 63, 240-248.

Hoyer, P.B. \& Kong, W. (1989) Protein kinase A and C activities and endogenous substrates in ovine small and large luteal cells. Molec. cell. Endocrinol. 62, 203-215.

Hoyer, P.B. \& Marion, S.L. (1989) Influence of agents that affect intracellular calcium regulation on progesterone secretion in small and large luteal cells of the sheep. J. Reprod. Fert. 86, 445-455.

Hoyer, P.B. \& Niswender, G.D. (1984) Hormone independent activation of adenylate cyclase in large steroidogenic ovine luteal cells does not result in increased progesterone secretion. Endocrinology 114, 604-608.

Hoyer, P.B. \& Niswender, G.D. (1986) Adenosine 3',5'monophosphate-binding capacity in small and large ovine luteal cells. Endocrinology 119, 1822-1829.

Huckle, W.R. \& Conn, P.M. (1987) Use of lithium ion in measurement of stimulated pituitary inositol phospholipid turnover. Methads in Enzymology 141, 149-155.

Jacobs, A.L., Homanies, G.E. \& Silvia, W.J. (1987) Effects of prostaglandin (PG) $\mathrm{GF}_{2 a}, \mathrm{PGE}_{2}$ and luteinizing hormone $(\mathrm{LH})$ on activity of phospholipase $\mathrm{C}$ in ovine Juteal tissue. J. Anim. Sci. 65 (Suppl. 1), Abstr. 409.

Jaken, S. \& Leach, K.L. (1988) Isozymes of protein kinase C. Ann. Reports Med. Chem. 23, 243-252.

Koos, R. \& Hansel, W. (1981) The large and small cells of the bovine corpus luteum: ultrastructural and functional differences. In Dynamics of Ovarian Function, pp. 197-203. Eds N, B. Schwartz \& M. HunzickerDunn. Raven Press, New York.

Kosaka, Y., Ogita, K., Ase, K., Nomura, H., Kikkawa, U. \& Nishizuka, Y. (1988) The heterogeneity of protein kinase $\mathrm{C}$ in various rat tissues. Biochem. Biophys: Res. Commun. 151, 973-981.

Kuno, M. \& Gardner, P. (1987) Ion channels activated by inositol 1,4,5-1risphosphate in plasma membrane of human T-lymphocytes. Nature, Lond. 326, 30I-304.

Lapetina, E.G. \& Siess, W. (1987) Measurement of inositol phospholipid turnover in platelets. Methods in Enzymology 141, 176-192.

Leung, P.C.K. (1985) Mechanisms of gonadotropinreleasing hormone and prostaglandin action on luteal cells. Can. J. Physiol. Pharmacol. 63, 249-256.

Leung, P.C.K. \& Wang, J. (1989) The role of inositol lipid metabolism in the ovary. Biol. Reprod. 40, 703-708.

Leung, P.C.K., Minegishi, T., Ma, F., Zhou, F. \& Ho-Yuen, B. (1986) Induction of polyphosphoinositide breakdown in rat corpus luteum by prostaglandin $\mathrm{F}_{2 u^{*}}$ Endocrinology 119,12-I8.

Leung, P.C.K., Rodway, M., Wang, J. \& Baimbridge, K.G. (1989) Effect of prostaglandin $F_{2 \pi}$ on cytosolic free calcium ion concentrations in rat ovarian cells. $l$. Reprod. Fert, Abstr. Ser. 3, 25, abstr. 
Litch, S.J. \& Condon, W.A. (1988) Interaction of hCG and Lutalyse on steroidogenesis of bovine luteal cells. Molec cell. Endocrinal. 57, 81-85.

Mattson, M.P., Guthrie, P.B. \& Kater, S.B. (1988) Intracellular messengers in the generation and degeneration of hippocampal neuroarchitecture. J. Neurosci. Res. 21, 447-464.

Mayer, M.L. \& Westbrook, G.L. (1987) Cellular mechanisms underlying excitotoxicity. Trends Neurosci. 10, 59-61.

Murdoch, W.J. (1987) Treatment of sheep with prostaglandin $\mathrm{F}_{20}$ enhances production of a luteal chemoattractant for eosinophils. Am. J. Reprod. Immun. Microbiol. 15, 52-56.

Nakadate, T., Jeng, A.Y. \& Blumber, P.M. (1988) Comparison of protein kinase $C$ functional assays to clarify mechanisms of inhibitor action. Biochem. Pharmacol. 37, $1541-1545$.

Nishizuka, Y. (1986) Studies and perspectives of protein kinase C. Science, $N Y 233,305-311$

Niswender, G.D. \& Nett, T.M. (1988) The corpus luteum and its control. In The Physiology of Reproduction. vol. I, pp. 489-526. Eds E. Knobil \& J. Neill. Raven Press, New York.

Niswender, G.D., Moore, R.T., Akbar, A.M., Nett, T.M. \& Diekman, M.A. (1975) Flow of blood to the ovaries of ewes throughout the estrous cycle. Biol. Reprod. 13, 381-388.

Noland, T.A., Jr \& Dimino, M.J. (1986) Characterization and distribution of protein kinase $C$ in ovarian tissue. Biol. Reprod. 35, 863-872.

Pate, J.L. \& Nephew, K.P. (1988) Effects of in vivo and in vitro adninistration of prostaglandin $\mathrm{F}_{20}$ on lipoprotein utilization in cultured bovine luteal cells. Biol. Reprod. 38, 568-576.

Rando, R.R. (1988) Regulation of protein kinase C activity by lipids. FASEB J. 2, 2348-2355.

Rodgers, R.J,, O'Shea, J.D. \& Bruce, N.W. (1984) Morphometric analysis of the cellular composition of the ovine corpus luteum. J. Anat, 138, 757-769.

Schwall, R.H., Sawyer, H.R. \& Niswender, G.D. (1986) Differential regulation by $\mathrm{LH}$ and prostaglandins of steroidogenesis in small and large luteal cells of the ewe. J. Reprod. Fert. 76, 821-829.

Speroff, L.P. \& Ramwell, W. (1970) Prostaglandin stimulation of in vitro progesterone synthesis. J. clin. Endocr. Melab. 30, 345-350.

Taylor, M.J. \& Clark, C.L. (1988) Stimulatory effect of phorbol diester on relaxin release by porcine luteal cells in culture. Biol, Reprod, 39, 743-750.

Thomas, T.P., Gopalakrishna, R. \& Anderson, W.B. (1987) Hormone- and tumor-promoter-induced activation of membrane association of protein kinase
C in intact cells. Methods in Enzymology 141, $399-411$.

Toaff, M.E., Schelyer, H. \& Strauss, J.F., III (1982) Metabolism of 25-hydroxycholesterol by rat luteal mitochondria and dispersed cells. Endocrinology 111, 1785-1790.

Ursely, J. \& Leymarie, P. (1979) Varying response to luteinizing hormone of two luteal cell types isolated from bovine corpus luteum. J. Endocr. 83, 303-310.

Veldhuis, J.D. (1987) Prostaglandin initiates polyphosphatidylinositol hydrolysis and membrane translocation of protein kinase $\mathrm{C}$ in swine ovarian cells. Biochem. Biophys. Res. Commun. 149, 112-117.

Veldhuis, J.D. \& Demers, L.M. (1987) Activation of protein kinase $\mathrm{C}$ is coupled to prostaglandin $\mathrm{F}_{2 \alpha}$ synthesis in the ovary: studies in cultured swine granulosa cells. Molec. cell, Endocr. 49, 249-254.

Wheeler, M.B. \& Veldhuis, J.D. (1987) Catalytic and receptor-binding properties of the calcium-sensitive phospholipid-dependent protein kinase (protein kinase C) in swine luteal cytosol. Molec. cell. Endocr. 50, 123-129.

Wheeler, M.B. \& Veldhuis, J.D. (1989) Purification of three forms of chromatographically distinct protein kinase C from the swine ovary. Molec. cell. Endoct. 61, $117-122$.

Wiltbank, M.C.,Kater,S.B., Guthrie, P.B., Mattson, M.P. \& Niswender, G.D. (1989a) Hormonal regulation of free intracellular calcium concentrations in small and large ovine luteal cells. Biol. Reprod. 41, 771-778.

Wiltbank, M.C., Knickerbocker, J.J. \& Niswender, G.D. (1989b) Regulation of the corpus luteum by protein kinase C. I. Phosphorylation activity and steroidogenic action in large and small ovine luteal cells. Biol. Reprod. 40, 1194-1200.

Wiltbank, M.C., Diskin, M.G., Flores, J.P. \& Niswender, G.D. (1990a) Regulation of the corpus luteum by protein kinase C. II. Inhibition of lipoprotein-stimulated steroidogenesis by prostaglandin $\mathrm{F}_{20}$. Biol. Reprod., in press.

Wiltbank, M.C., Gallagher, K.P., Christensen, A.K., Brabec, R.K. \& Keyes, P.L. (1990b) Physiological and immunocytochemical evidence for a new concept of blood flow regulation in the corpus luteum. Biol, Reprod., in press.

Witters, L.A. \& Blackshear, P.J. (1987) Protein kinase C-mediated phosphorylation in intact cells. Methods in Enzymology 141, 412-424.

Zelinski, M.B., Selivonchick, D.P. \& Stormshak, F. (1988) Characterization of plasma membrane lipids and luteinizing hormone receptors of ovine corpora lutea during luteolysis and early pregnancy. Biol. Reprod. 38, 768-779. 
